\title{
Morphological, sediment and soil chemical characteristics of dry tropical shallow reservoirs in the Southern Mexican Highlands
}

\author{
Guillermo ALDAMA-ROJAS ${ }^{1,2)}$, Jesús Trinidad PONCE-PALAFOX ${ }^{3,2) *}$, Delfino MADRIGAL-URIBE ${ }^{1,4)}$, \\ José MONROY-GAYTÁN ${ }^{1,4)}$, Luis Fernando CRUZ-GARCIA ${ }^{2)}$ and José Luis ARREDONDO-FIGUEROA ${ }^{5)}$ \\ ${ }^{1)}$ Posgrado en Ciencias Ambientales, Universidad Autónoma del Estado de México, Paseo Tollocan Isidro Fabela, Toluca de Lerdo, \\ México C.P. 50170 \\ ${ }^{2)}$ Laboratorio de Bioingeniería Acuícola, Centro de Investigaciones Biológicas, Universidad Autónoma del Estado de Morelos, Av. \\ Universidad No. 1001 Col. Chamilpa, Cuernavaca, Morelos, México C.P. 62209 \\ ${ }^{3)}$ Centro Nayarita de Innovación y Desarrollo Tecnológico (CENITT), Universidad Autónoma de Nayarit-Posgrado CBAP, Cda. de \\ la Cultura Amado Nervo, Col. Menchaca Tepic, Nayarit, México C.P. 63150 \\ ${ }^{4)}$ Laboratorio de Geografía Ambiental y Sistemas de Información Geográfica. Facultad de Geografía, U.A.E.M. Paseo Tollocan \\ Isidro Fabela, Toluca de Lerdo 50170, Toluca, Edo. de México, México C.P. 50000 \\ ${ }^{5}$ Universidad Autónoma Metropolitana Iztapalapa. División de CBS, Departamento de Hidrobiología, Planta Experimental de \\ Producción Acuícola, Av. San Rafael Atlixco No.186, Col.Vicentina C.P. 09340 Del. Iztapalapa, México D.F. \\ *e-mail corresponding author: jesus.ponce@usa.net
}

\begin{abstract}
The morphometry, sediment and soil chemical characteristics of eleven dry tropical shallow reservoirs situated in Southern Mexican Highlands were studied. The reservoirs are located at 1104 to 1183 meters above sea level in a sedimentary area. Seventeen morphometric and eight sediment and soil chemical parameters were measured. The results of the morphometric parameters showed that these reservoirs presented a soft and roughness bottom, with an ellipsoid form and a concave depression that permit the mix up of water and sediments, causing turbidity and broken thermal gradients; their slight slopes allowed the colonization of submerged macrophyte and halophyte plants and improved the incidence of sunlight on water surface increasing evaporation and primary productivity. Dry tropical shallow reservoirs have fluctuations in area, and volume according to the amount of rainfall, the effect of evaporation, temperature, lost volume for irrigation, and other causes. The sand-clay was the most important sediment texture and their values fluctuated with the flooded periods. The concentration-dilution cycle showed a direct relationship in the percentage of organic matter in the soil as well as with $\mathrm{pH}$, soil nitrogen and phosphorus. El Tilzate, El Candelero and El Movil were related by the shore development and high concentrations of organic matter and nitrogen in the soil. Finally, we emphasize the importance of this study, in relation to possible future changes in morphometrical parameters as a consequence of human impact.
\end{abstract}

Key words: Morphometry, bathymetry, soil chemical characteristics, tropical shallow reservoirs, Southern Mexican Highlands

\section{INTRODUCTION}

A limnological description of dry tropical shallow reservoirs is a necessary step in the research of the aquatic ecosystem (Håkanson 1981). The morphology of shallow reservoir basin exerts a major control over a wide range of processes and features in a lacustrine ecosystem and reflects a series of actions closely related to its origin, operation and use.

One of the oldest limnological principles is that basin morphometry influences lake metabolism (Thienemann 1925; Neumann 1932), as a consequence, many studies have demonstrated how tropical shallow reservoirs morphometry affects the rate of certain limnological processes and the distribution of physical, chemical and biological parameters (Ponce-Palafox et al. 1998), phytoplankton and submerged macrophyte abundance, structure and production (Schindler 1971; Duarte \& Kalff 1988; Pinel-Alloul et al. 1990), loading, dilution and recycling of nutrients (Pick \& Lean 1987), ratio of nitrogen to phosphorus (Smith 1982), light in surface layer (Sterner 1990), sediment focusing (Blais \& Kalff 1995), thermal structure (Robertson \& Ragotzkie 1990), and phytoplankton structure (Eloranta 1986). In this sense Guiral \& Pérez (1980) pointed out the importance of the cartography and morphometry of lake ecosystems as a first step in any kind of limnological research.

The majority of the morphometric analyses carry out on tropical shallow reservoirs have been based on measures of surface dimensions in different basins (PoncePalafox et al. 1998), but this type of study is insufficient to establish a good relationship between physico-chemical and biological parameters, and for elaboration of a good integrated management plan. It would be necessary to include a more detailed analysis of morphometrical parameters of both, surface and subsurface dimensions. In dry tropical shallow reservoirs of Latin America there are few studies on morphometric parameters. This research aim contributes to this type of knowledge 


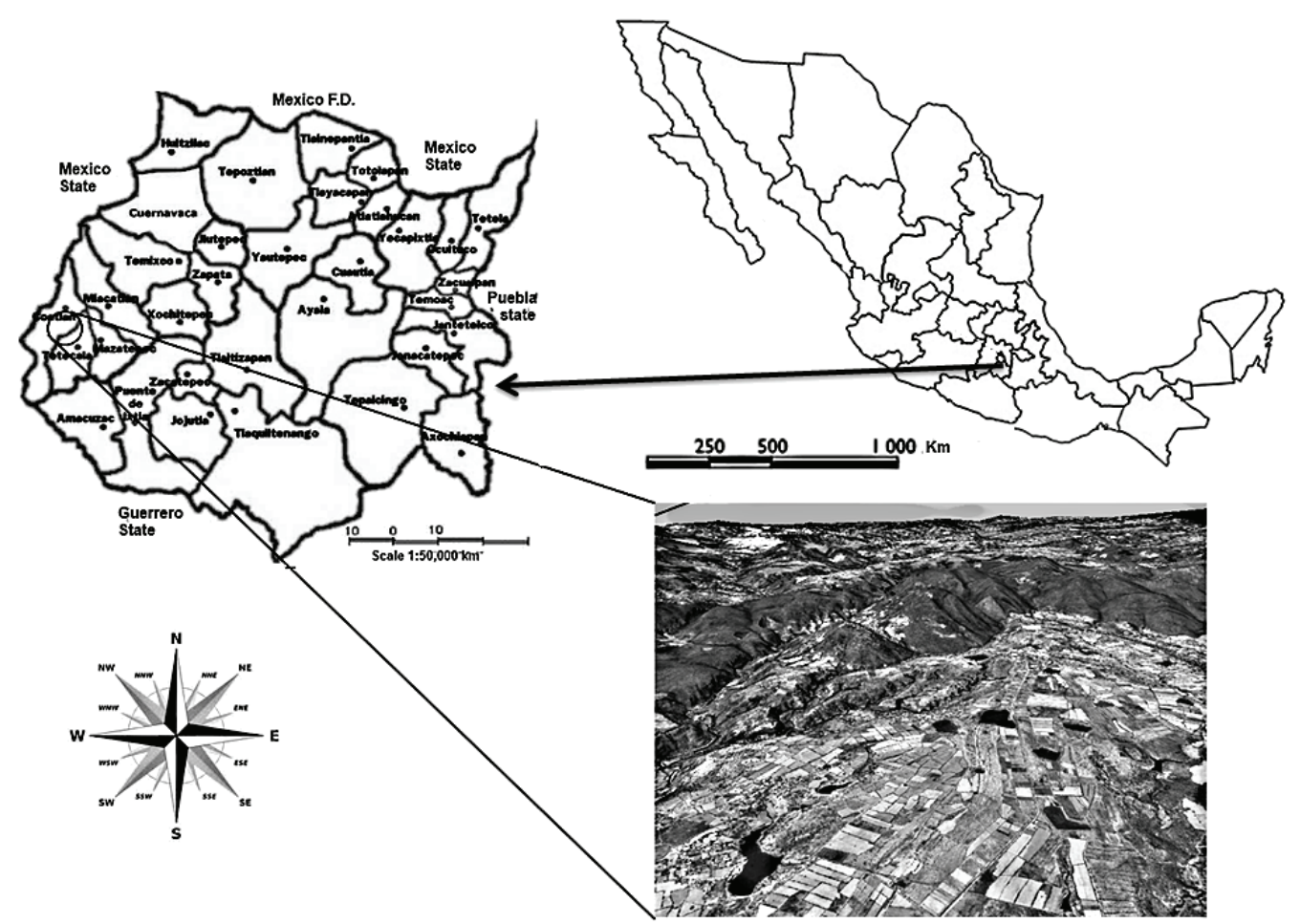

Fig. 1. Geographic location of the dry tropical shallow reservoirs in the southern Mexican highlands.

by means of morphometric, sediment and soil chemical studies in tropical shallows reservoirs in the Southern Mexican Highlands. This study complements previous works realized by Ponce-Palafox and ArredondoFigueroa (1986) and Ponce-Palafox et al. (1998), and can be used as a basis for future limnological studies.

\subsection{Study area}

The dry tropical shallow reservoirs are located in the geographic coordinates $18^{\circ} 39^{\prime} 44^{\prime \prime} \mathrm{N}: 99^{\circ} 26^{\prime} 38^{\prime \prime} \mathrm{W}$; $18^{\circ} 42^{\prime} 09^{\prime \prime} \mathrm{N}: 9^{\circ} 28^{\prime} 19^{\prime \prime} \mathrm{W}$ in the extreme southwest of the State of Morelos, Mexico (Fig. 1). They border north and west with the State of Mexico, south with the municipalities of Amacuzac and Tetecala, east with Tetecala and Miacatlán, and west with the State of Guerrero. Eleven reservoirs named El Tilcuate, Contlalco, El Tilzate, Laguna de En medio, Laguna Seca, El Movil, El Candelero, Las Alzadas, Las Guayabitas, La Nopalera and Michapa were studied, with a surface ranging from two to ten hectare. Eight reservoirs are semipermanent and three of them temporary, with an altitude from 1104 to 1183 meters above sea level in a sedimentary soil area. The climate is warm, sub-humid with summer rains and a dry season in winter. The hottest months are April and May, while the coldest months are December and January. The average precipitation is 1000 millimeters per year. Maximum temperature is $34.0^{\circ} \mathrm{C}$, average $24.0^{\circ} \mathrm{C}$ and minimum $14.0^{\circ} \mathrm{C}$. From a hydrological point of view, dry tropical shallow reservoirs receive direct supply from rainfall, groundwater flow, and surface runoff from sporadic streams.

\section{METHODS}

\subsection{Morphometric parameters}

The construction of a bathymetric or contour map was performed during three different periods of the flood cycle, flooding during periods of minimum, medium and maximum. The depth was determined at the deepest point near the gate of the reservoir, using a manual probe graduated in centimeters. The technique of separate segments was used in order to prepare the contour map, measuring the perimeter of coastline with a fiberglass 30 meter ADIR coated PVC tape measure graduated in centimeters and inches and resistant to extreme temperatures. To integrate the superimposed line segments to the coast, we used a Directional compass Engineer orienting the segments according to the degrees of the four main directions (azimuth). Once in the laboratory, was performed the outline with the stroke of oriented segments in cumulative sequence completing the circuit, using the scale 1:400. Contour intervals were $0.5 \mathrm{~m}$. The morphometric analysis followed Håkanson (1981).

\subsection{Sedimentological and soil chemical characterization}

Six sediment samples were collected in the dry season and six in the rainy season, when the reservoirs began desiccation process and the maximum depth was less than $0.5 \mathrm{~m}$. Samples were taken at three different points distributed randomly within the reservoir basin, 
Tab. 1. Morphometric parameters of the dry tropical shallow reservoirs in the south-west of the State of Morelos. Shallow reservoirs: 1 =Tilcuate; 2 = Laguna Seca; 3 = Tilzate; $4=$ Candelero; $5=$ Michapa; $6=$ En medio; $7=$ Guayabitos; 8 = Alzadas; 9 = El Móvil; $10=$ Contlalco; 11= Nopalera.

\begin{tabular}{|c|c|c|c|c|c|c|c|c|c|c|c|}
\hline \multirow[t]{2}{*}{ Parameters } & \multicolumn{11}{|c|}{ Shallow reservoirs } \\
\hline & 1 & 2 & 3 & 4 & 5 & 6 & 7 & 8 & 9 & 10 & 11 \\
\hline Area $\left(\mathrm{m}^{2}\right)$ & 128,000 & 67,196 & 48,952 & 45,588 & 45,496 & 43,416 & 42,868 & 41,872 & 38,112 & 34,316 & 32,644 \\
\hline Volume $\left(\mathrm{m}^{3}\right)$ & 694,095 & 50,001 & 122,971 & 101,926 & 40,532 & 28,821 & 72,826 & 136,859 & 86,783 & 37,110 & 67,793 \\
\hline Mean depth (m) & 5.42 & 0.74 & 2.51 & 2.24 & 0.89 & 0.66 & 1.70 & 3.27 & 2.28 & 1.08 & 2.08 \\
\hline Maximum depth (m) & 9.70 & 1.50 & 5.80 & 4.75 & 1.50 & 5.80 & 3.35 & 6.90 & 5.10 & 2.00 & 4.40 \\
\hline Relative depth (m) & 2.40 & 0.51 & 2.32 & 1.97 & 0.62 & 2.47 & 1.43 & 2.99 & 2.32 & 0.96 & 2.16 \\
\hline Shoreline length (m) & 2820 & 1014 & 930 & 900 & 886 & 810 & 780 & 820 & 840 & 692 & 728 \\
\hline Shore development & 2.22 & 1.10 & 1.19 & 1.19 & 1.17 & 1.10 & 1.06 & 1.13 & 1.21 & 1.05 & 1.14 \\
\hline Maximum length (m) & 720 & 380 & 330 & 302 & 290 & 240 & 272 & 320 & 252 & 240 & 240 \\
\hline Maximum width (m) & 350 & 280 & 220 & 222 & 230 & 240 & 190 & 144 & 142 & 190 & 170 \\
\hline Mean width (m) & 177.8 & 176.8 & 142.9 & 151 & 156.9 & 148.4 & 157.6 & 130.9 & 151.2 & 180.9 & 135.1 \\
\hline Maximum depth (m) & 9.70 & 1.50 & 5.80 & 4.75 & 1.50 & 5.80 & 3.35 & 6.90 & 5.10 & 2.00 & 4.40 \\
\hline Depth ratio $\left(Z_{\text {mean }} Z_{\max }^{-1}\right)$ & 0.56 & 0.49 & 0.43 & 0.47 & 0.59 & 0.11 & 0.51 & 0.47 & 0.45 & 0.54 & 0.47 \\
\hline Volume development & 1.68 & 1.49 & 1.62 & 1.41 & 1.8 & 1.3 & 1.52 & 1.42 & 1.34 & 1.15 & 1.46 \\
\hline $\mathrm{Vd}^{-1}(\%)$ & 56.0 & 49.7 & 54.0 & 47.0 & 60.0 & 43.3 & 50.7 & 47.3 & 44.7 & 38.3 & 48.7 \\
\hline $1-\mathrm{Vd} 3^{-1}(\%)$ & 44.0 & 50.3 & 46.0 & 53.0 & 40.0 & 56.7 & 49.3 & 52.7 & 55.3 & 61.7 & 51.3 \\
\hline Dynamic ratio & 0.66 & 0.35 & 0.17 & 0.09 & 0.24 & 0.09 & 0.12 & 0.06 & 0.09 & 0.31 & 0.09 \\
\hline Direction of major axis & Southwest & East & South & East & Southeast & East & East & East & East & Southwest & East \\
\hline
\end{tabular}

to $5 \mathrm{~cm}$ deep. A granulometric study was carried out by sieving the sediment sample and analyzed in a Robinson pipette with the following fractions: clay $(<2 \mu \mathrm{m})$, silt $(2-50 \mu \mathrm{m})$ and sand $(50-2000 \mu \mathrm{m})($ Soil Conservation Service 1972). Gravel fractions ( $>2 \mathrm{~mm})$ were not detected. Other analyses were carried out on the fine fractions of the sediment $(<2 \mathrm{~mm})$, the organic carbon content was calculated by the dichromate oxidation method and $\mathrm{pH}$ in a 1:1 fine fraction: water suspension $\left(\mathrm{w} \mathrm{w}^{-1}\right)$ according to Wolt (1994). Organic matter content was estimated by multiplying organic carbon percentage by a correction factor of 1.724 (Soil Survey Staff 1999). Analysis of soil nitrogen and phosphorus was performed according to Castellanos et al. (2000).

\subsection{Cluster analysis}

To examine the morphology, sediment and soil chemical characteristics of dry tropical shallow reservoirs, agglomerative weighted pair-group average and Euclidean distances were used according to PoncePalafox et al. (1998).

\section{RESULTS AND DISCUSSION}

\subsection{Morphometric parameters}

The shallow reservoirs are supplied with rain water and runoff from the mountains located at north; the upper basin is occupied by a zone induced grassland that is considered a Municipal Ecological Reserve. The land has a gentle slope with north - south direction so that when it rains the water current drags sediments, which are deposited, in the shallow reservoirs. The watershed that drains into the reservoirs has an elongated shape with northwest - southeast orientation, with one single basin. These water bodies have fluctuations in area and volume, according to the amount of rainfall, the effect of evaporation, lost volume by irrigation, and other causes. Leakage is caused by loss of sediment to provoke the so-called lateral loans (Naselli-Flores 2003).

Their maximum capacity fluctuated from 32,644 to $128,000 \mathrm{~m}^{2}$ with an average of $51,678 \mathrm{~m}^{2}$, they are shallow with a maximum depth from 2.0 to 6.9 meters, and only one reaches 9.7 meters. The morphometrical parameters of the dry tropical shallow reservoirs are shown in table 1. Among these parameters, the mean depth $\left(\mathrm{Z}_{\text {mean }}\right)$ is probably the most important morphometric feature because it could be related with the productivity and trophic status (Håkanson 1981). The shallow reservoirs presented an average $Z_{\text {mean }}$ of $2.1 \pm 1.4$, indicating that their bottom is soft, easily removed and mixed with the water column causing turbidity. They serve as a surrogate for most morphometric attributes and a host of biological processes, but no correlation could provide with unambiguous information on underlying causes (Kalff 2002). However, a low value of $Z_{\text {mean }}$ normally tends to show high levels of nutrients in water and consequently is a productivity indicator (Sakamoto 1966). Moreover, mean depth may be used to determine the lake bottom roughness, which is a useful parameter in sedimentological studies and in the optimization models for lake hydrographical surveys (Håkanson 1981).

Neumann (1959) concluded that the depth ratio $\left(Z_{\text {mean }} Z_{\max }{ }^{-1}\right)$ provides a useful approximation to lake form. The shallow reservoirs showed an average value of 0.56 , similar to an ellipsoid form that it is characteristic of shallow lakes with flat bottoms (Carpenter 1983). Also showed a relative depth (Dr) ranging between 0.51 to $2.40 \mathrm{~m}$. These values are related with the stability of the column of water and the stratification process that is typical of small and shallow basins. Shore development was near of one and it represents a measure of the irregularity of the shoreline (Håkanson 1981), which is one of the morphological parameters that reflects processes related to the lakes' origin. Dyna- 
Tab. 2. Texture and soil chemical characteristics parameters of the dry tropical shallow reservoirs in the south-west of the State of Morelos. $\mathrm{C}=$ Concentration; $\mathrm{D}=$ Dilution. Shallow reservoirs: 1 =Tilcuate; 2 = Laguna Seca; $3=$ Tilzate; $4=$ Candelero; $5=$ Michapa; 6 = En medio; $7=$ Guayabitos; $8=$ Alzadas; $9=$ El Móvil; $10=$ Contlalco; $11=$ Nopalera.

\begin{tabular}{|c|c|c|c|c|c|c|c|c|c|c|c|}
\hline \multirow[t]{2}{*}{ Parameters } & \multicolumn{11}{|c|}{ Shallow reservoirs } \\
\hline & 1 & 2 & 3 & 4 & 5 & 6 & 7 & 8 & 9 & 10 & 11 \\
\hline Sand (\%) & $\begin{array}{l}C=68.60 \\
D=92.92\end{array}$ & $\begin{array}{l}C=24.60 \\
D=47.28\end{array}$ & $\begin{array}{l}C=58.60 \\
D=86.92\end{array}$ & $\begin{array}{l}C=34.60 \\
D=67.82\end{array}$ & $\begin{array}{l}C=36.60 \\
D=58.92\end{array}$ & $\begin{array}{l}C=60.60 \\
D=90.92\end{array}$ & $\begin{array}{l}C=40.62 \\
D=68.92\end{array}$ & $\begin{array}{c}C=66.6 \\
D=88.92\end{array}$ & $\begin{array}{l}C=18.60 \\
D=91.28\end{array}$ & $\begin{array}{c}C=32.6 \\
D=69.28\end{array}$ & $\begin{array}{l}C=60.60 \\
D=58.92\end{array}$ \\
\hline Silt (\%) & $\begin{array}{c}C=18.72 \\
D=3.84\end{array}$ & $\begin{array}{l}C=28.72 \\
D=20.92\end{array}$ & $\begin{array}{c}\mathrm{C}=22.72 \\
\mathrm{D}=9.84\end{array}$ & $\begin{array}{l}C=24.72 \\
D=18.92\end{array}$ & $\begin{array}{l}C=24.72 \\
D=17.84\end{array}$ & $\begin{array}{c}C=24.72 \\
D=5.84\end{array}$ & $\begin{array}{c}C=26.72 \\
D=9.84\end{array}$ & $\begin{array}{c}C=18.72 \\
D=7.84\end{array}$ & $\begin{array}{c}C=28.72 \\
D=2.92\end{array}$ & $\begin{array}{l}C=30.72 \\
D=24.92\end{array}$ & $\begin{array}{l}C=16.72 \\
D=15.84\end{array}$ \\
\hline Clay (\%) & $\begin{array}{c}C=12.68 \\
D=3.24\end{array}$ & $\begin{array}{c}C=46.68 \\
D=31.8\end{array}$ & $\begin{array}{c}C=18.68 \\
D=3.24\end{array}$ & $\begin{array}{c}C=40.68 \\
D=13.8\end{array}$ & $\begin{array}{l}C=38.58 \\
D=23.24\end{array}$ & $\begin{array}{c}C=14.68 \\
D=3.24\end{array}$ & $\begin{array}{l}C=32.68 \\
D=21.24\end{array}$ & $\begin{array}{c}C=14.68 \\
D=3.24\end{array}$ & $\begin{array}{c}C=52.68 \\
D=5.8\end{array}$ & $\begin{array}{c}C=36.28 \\
D=5.8\end{array}$ & $\begin{array}{l}C=22.68 \\
D=25.24\end{array}$ \\
\hline Texture & $\begin{array}{c}\mathrm{C}=\text { crumbly- } \\
\text { sandy } \\
\mathrm{D}=\text { sandy }\end{array}$ & $\begin{array}{c}\mathrm{C}=\text { clay } \\
\mathrm{D}=\text { clay - } \\
\text { crumbly - } \\
\text { sandy }\end{array}$ & $\begin{array}{c}\mathrm{C}=\text { crumbly - } \\
\text { sandy } \\
\mathrm{D}=\text { sandy }\end{array}$ & $\begin{array}{c}\mathrm{C}=\text { clay } \\
\mathrm{D}=\text { crumbly }- \\
\text { sandy }\end{array}$ & $\begin{array}{l}\mathrm{C}=\text { crumbly }-\mathrm{C} \\
\quad \text { clay } \\
\mathrm{D}=\text { crumbly - } \\
\text { clay - sandy }\end{array}$ & $\begin{array}{c}\mathrm{C}=\text { crumbly - } \\
\text { sandy } \\
\mathrm{D}=\text { sandy }\end{array}$ & $\begin{array}{c}\mathrm{C}=\text { crumbly }-\mathrm{C} \\
\text { sandy } \\
\mathrm{D}=\text { crumbly - } \\
\text { clay - sandy }\end{array}$ & $\begin{array}{c}\mathrm{C}=\text { crumbly - } \\
\text { sandy } \\
\mathrm{D}=\text { sandy }\end{array}$ & $\begin{aligned} C & =\text { clay } \\
D & =\text { sandy }\end{aligned}$ & $\begin{array}{c}\mathrm{C}=\text { crumbly }- \\
\quad \text { clay } \\
\mathrm{D}=\text { crumbly- } \\
\text { sandy }\end{array}$ & $\begin{array}{l}\mathrm{C}=\text { crumbly - } \\
\text { clay - sandy } \\
\mathrm{D}=\text { crumbly - } \\
\text { clay - sandy }\end{array}$ \\
\hline Organic matter (\%) & $\begin{array}{c}\mathrm{C}=2.23 \\
\mathrm{D}=2.8\end{array}$ & $\begin{array}{c}C=3.77 \\
D=2.3\end{array}$ & $\begin{array}{c}C=0.84 \\
D=6.9\end{array}$ & $\begin{array}{c}C=5.30 \\
D=1.4\end{array}$ & $\begin{array}{c}C=4.33 \\
D=1.4\end{array}$ & $\begin{array}{c}C=3.63 \\
D=2.3\end{array}$ & $\begin{array}{c}C=4.46 \\
D=1.4\end{array}$ & $\begin{array}{c}C=9.7 \\
D=4.46\end{array}$ & $\begin{array}{c}C=5.30 \\
D=2.1\end{array}$ & $\begin{array}{c}C=4.05 \\
D=1.6\end{array}$ & $\begin{array}{c}C=2.65 \\
D=3.2\end{array}$ \\
\hline Nitrogen $\left(\mathrm{kg} \mathrm{ha}^{-1}\right)$ & $\begin{array}{c}C=80.0 \\
D=107.8\end{array}$ & $\begin{array}{c}C=135 \\
D=89.8\end{array}$ & $\begin{array}{c}C=30 \\
D=269.4\end{array}$ & $\begin{array}{l}C=190 \\
D=53.9\end{array}$ & $\begin{array}{l}C=156 \\
D=53.9\end{array}$ & $\begin{array}{c}C=130 \\
D=89.8\end{array}$ & $\begin{array}{l}C=160 \\
D=53.9\end{array}$ & $\begin{array}{c}C=377.2 \\
D=160\end{array}$ & $\begin{array}{c}C=190 \\
D=80.8\end{array}$ & $\begin{array}{l}C=150 \\
D=62.9\end{array}$ & $\begin{array}{c}C=95 \\
D=125.7\end{array}$ \\
\hline Phosphorus (mg L ${ }^{-1}$ ) & $\begin{array}{c}C=206 \\
D=17.8\end{array}$ & $\begin{array}{l}C=230 \\
D=15.6\end{array}$ & $\begin{array}{l}C=78.0 \\
D=38.5\end{array}$ & $\begin{array}{l}C=176 \\
D=3.0\end{array}$ & $\begin{array}{l}C=220 \\
D=39.6\end{array}$ & $\begin{array}{l}C=117 \\
D=107\end{array}$ & $\begin{array}{l}C=206 \\
D=19.9\end{array}$ & $\begin{array}{c}C=240 \\
D=15.6\end{array}$ & $\begin{array}{c}C=226 \\
D=67.8\end{array}$ & $\begin{array}{c}C=246 \\
D=114.6\end{array}$ & $\begin{array}{l}C=246 \\
D=132\end{array}$ \\
\hline $\mathrm{pH}$ & $\begin{array}{l}C=5.83 \\
D=6.19\end{array}$ & $\begin{array}{l}C=5.77 \\
D=5.91\end{array}$ & $\begin{array}{c}C=5.6 \\
D=6.71\end{array}$ & $\begin{array}{l}C=5.77 \\
D=6.03\end{array}$ & $\begin{array}{c}C=5.87 \\
D=6.8\end{array}$ & $\begin{array}{l}C=5.59 \\
D=6.16\end{array}$ & $\begin{array}{l}C=6.55 \\
D=5.78\end{array}$ & $\begin{array}{c}C=5.7 \\
D=6.15\end{array}$ & $\begin{array}{l}C=5.77 \\
D=6.08\end{array}$ & $\begin{array}{l}C=6.25 \\
D=6.04\end{array}$ & $\begin{array}{l}C=5.66 \\
D=6.31\end{array}$ \\
\hline
\end{tabular}

mic ratio (DR) is designed to represent bottom dynamic conditions (Lindström et al. 1999). The influence of this parameter over the diminishing of volume and other processes related to the water-sediment interface denoted its importance. The average dynamic ratio value of 0.21 indicates that there are lower bottom areas exposed to wind/wave energy. The developments of volume values were greater than one, which indicates a concave depression. The distribution coefficient $\left(\mathrm{V}_{\mathrm{d}} 3^{-1}\right)$ is a useful tool to know the amount of sediment available for re-suspension on the erosion and transport areas (ETareas), the fraction that goes to deep waters, and the fraction $\left(1-\mathrm{V}_{\mathrm{d}} 3^{-1}\right)$ that goes to surface waters (Håkanson et al. 2000). The values obtained mean that $49.0 \%$ of the matter available is transported to deep waters and $51.0 \%$ to surface waters.

The relative depth for all shallow reservoirs was above $2 \%$, which indicates the structure of daytime thermal discontinuities, however, in this case the water column is mixed by the effect of wind velocity over the maximum fetch in these reservoirs that fluctuated from 240 to $720 \mathrm{~m}$, resulting in a complete mixing, as a consequence the thermal gradient is eliminated. Shallow reservoirs have slight shore slopes, although there is some dissimilarity between the two shorelines. The slight slope allows for colonization of the sediment by submerged macrophytes and halophytes (Ortega \& Guerrero 2003).

The less shallow-slope reservoirs were El Tilcuate, Laguna Seca and Laguna de En Medio, this last one being saucer-shaped and having a higher ratio of surface area and maximum depth and bathymetric bit steep decline, reflected in an outstanding average of 4 to $5 \%$. This also improves the incidence of sunlight on the water surface, which increases the process of evaporation, therefore, heat loss, and gain in the water column increases primary productivity. The maximum length increases wind action creating movements that impact the entire mass of water throughout the day. This causes a greater exchange of material from the sediment (Barbanti 1985). A perfectly circular basin has a shore development of one; irregular basins have values greater than one. It is important to know shore development as a starting input of nutrients to the reservoir as a function of the perimeter. Theoretically similar lakes in all morphometric traits, with the highest shore development will be more productive (Castro et al. 2003). The El Tilcuate has the highest shore development with 2.2. El Tilzate, El Candelero, Michapa and El Movil follow it with 1.17 to 1.21 .

\subsection{Sedimentological and chemical soil characterization}

Results obtained from the sediment study showed that sand-clay is the most common texture in surface samples. The trend of soil texture in all the shallow reservoirs was to increase the proportion of sand, and clay decrease as the basin was flooded. This was due to washing of sediments from the watershed by carrying heavy material. The percentage of organic matter in the soil of the shallow reservoirs in general decreased (average 3.7 to $3.2 \%$ ) from minimum to maximum flood (Tab. 2). This was directly related to the concentrationdilution cycle. In the El Tilzate, Las Alzadas and La Nopalera the concentration increased with the period of flooding. In the Las Alzadas, concentration of organic matter was highest $\left(9.7 \mathrm{mg} \mathrm{L}^{-1}\right)$ at the stage of concentration and the lowest was 1.4 to $1.6 \mathrm{mg} \mathrm{L}^{-1}$ at El Candelero, Michapa, Las Guayabitas and Contlalco at the stage of dilution. Soil nutrients from reservoirs generally decreased (nitrogen: 153.9 to $104.3 \mathrm{~kg} \mathrm{ha}^{-1}$; phosphorus: 199.2 to $52.8 \mathrm{mg} \mathrm{L}^{-1}$ ) and the $\mathrm{pH}$ increased from 5.9 to 6.2 , from minimum to maximum flood. 


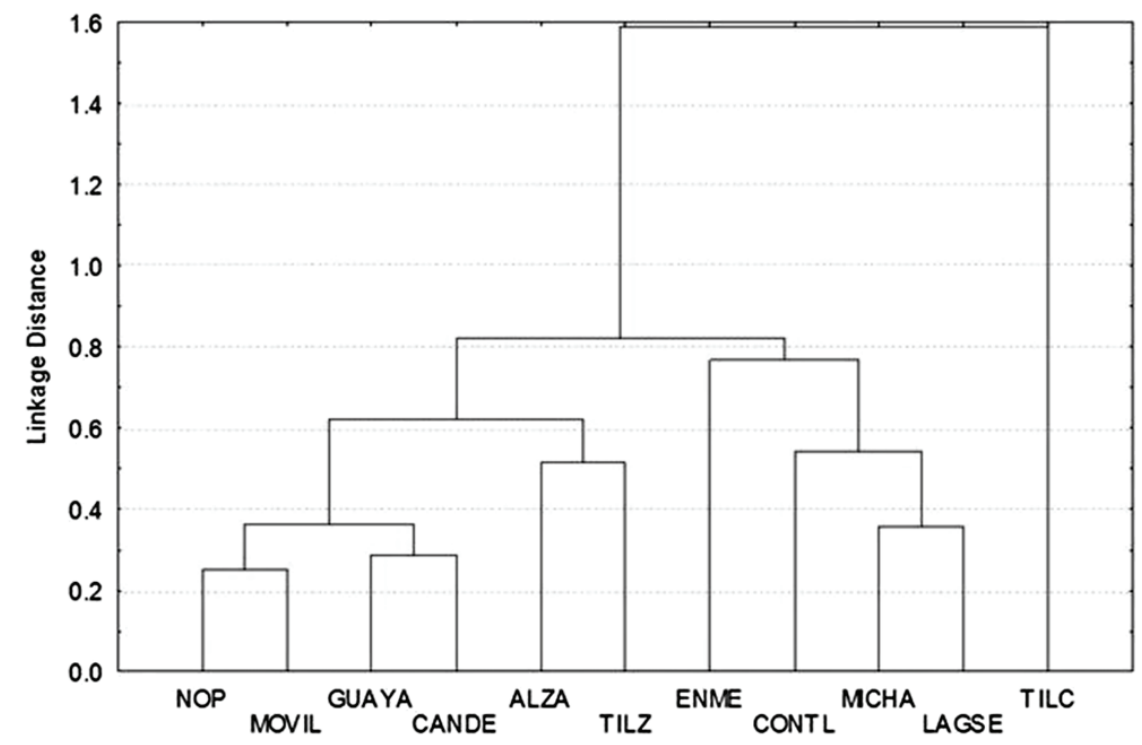

Fig. 2. Dendrogram of morphological and soil chemical characteristics on dry tropical shallow reservoirs. $(\mathrm{TIL}=\mathrm{Tilcuate}$; ENME $=$ Laguna de en Medio; CONTL= Contlalco; MICHA= Michapa; LAGSE = Laguna Seca; ALZA= Alzadas; TILZ = Tilzate; CANDE = Candelero; MOVIL= el Móvil; NOP = Nopalera; GUAYA = Guayabitos).

This was directly related to the concentration-dilution cycle and mineralization of the system.

\subsection{Cluster analysis}

The morphological, sediments and soil chemical characteristics of the reservoirs analyzed by cluster analysis showed two groups. The first was represented by El Tilcuate and the second by the rest of reservoirs which formed two subgroups a and b (Fig. 2). In the first subgroup (a) La Nopalera, el Movil, Las Guayabitas, El Candelero, Las Alzadas and El Tilzate reservoirs conform a cluster, and in the second subgroup (b) laguna de En Medio, Contlalco, Michapa and Laguna Seca reservoirs matched other. It was found that subgroup (a) in general has higher shore development and organic matter. Subgroup (b) has the highest dynamic proportions.

The Factor Loadings Extraction from the Principal Component Analysis (Tab. 3), indicated that the first component was related mainly to morphometric parameters (area, volume, shoreline length, shore development and maximum length), and the second component explained the relationship between some morphometric parameters and the percentage of organic matter, and soil nitrogen.

In general, it was found that El Tilzate, El Candelero and El Movil, are related with shore development and high concentrations of organic matter, and soil nitrogen. The hierarchical agglomerative cluster analysis (HACA) have been used as a efficient method to recognize groups of samples that have similar chemical and physical characteristics (Güler et al. 2002; Farnham et al. 2000) and in this research the method permitted distinguish relationships between the morphometric, sediment and soil chemistry parameter. Consequently, we want to emphasize the importance of this study in terms of possible future changes in morphological, sediment and soil chemical characteristics of dry tropical shallow as a result of the use and management of these reservoirs.

Tab. 3. Factor Loadings Extraction: Principal components (Marked loadings are $>0.700000$ ) of parameters morphological and chemical characteristics of soil on dry tropical reservoirs.

\begin{tabular}{|c|c|c|}
\hline Parameters & Component 1 & Component 2 \\
\hline Area $\left(m^{2}\right)$ & $0.880841^{* *}$ & -0.305477 \\
\hline Volume $\left(\mathrm{m}^{3}\right)$ & $0.893427 * *$ & 0.206866 \\
\hline Mean depth (m) & $0.736072 * *$ & 0.431480 \\
\hline Maximum depth (m) & 0.596731 & $0.740565^{* *}$ \\
\hline Relative depth (m) & 0.323230 & $0.899870 * *$ \\
\hline Shoreline length (m) & $0.939272 * *$ & -0.198855 \\
\hline Shore development & $0.922058 * *$ & -0.095292 \\
\hline Maximum length (m) & $0.926515^{* *}$ & -0.203611 \\
\hline Maximum width (m) & 0.614552 & -0.560551 \\
\hline Mean width (m) & 0.173374 & $-0.790629 * *$ \\
\hline Depth ratio & 0.228598 & -0.465036 \\
\hline Volume development & 0.638918 & -0.294727 \\
\hline${\operatorname{Vd~} 3^{-1}(\%)}$ & -0.630846 & 0.326809 \\
\hline $1-\mathrm{Vd}^{-1}(\%)$ & 0.636355 & -0.304551 \\
\hline Dynamic ratio & 0.652847 & -0.599337 \\
\hline Sand $(\%)$ & -0.586775 & -0.690058 \\
\hline Silt (\%) & 0.601981 & 0.637321 \\
\hline Clay $(\%)$ & 0.468970 & 0.660445 \\
\hline Organic matter (\%) & 0.048471 & $-0.721121 * *$ \\
\hline Nitrogen $\left(\mathrm{kg} \mathrm{ha}^{-1}\right)$ & -0.083397 & $0.746596^{* *}$ \\
\hline Phosphorus (mg L $\left.{ }^{-1}\right)$ & -0.434369 & -0.180237 \\
\hline $\mathrm{pH}$ & 0.040104 & -0.368525 \\
\hline
\end{tabular}

\section{CONCLUSIONS}

Dry tropical shallow reservoirs have fluctuations in area, and volume according to the amount of rainfall, the effect of evaporation, temperature, lost volume for irrigation, and other causes. Leakage is caused by loss 
of sediment so-called lateral loans. Shallow reservoirs showed a mean depth ratio $\left(Z_{\operatorname{mean}} Z_{\max }{ }^{-1}\right)$ of 0.56 similar to an ellipsoid form that is characteristic of shallow lakes with flat bottoms. The relative depth for all shallow reservoirs was above $2 \%$, which indicates the structure of daytime thermal discontinuities. The sediment shows that sand-clay is the most common texture in surface samples. The trend of soil texture in all the shallow reservoirs was to increase the proportion of sand, and clay decrease as the basin was flooded. The percentage of organic matter in the soil of the shallow reservoirs in general decreased (mean 3.7 to $3.2 \%$ ) from minimum to maximum flood. La Nopalera, el Movil, Las Guayabitas, El Candelero, Las Alzadas and El Tilzate reservoirs had the highest shore development and organic matter. In general, it was found that El Tilzate, El Candelero and El Movil are related by the shore development and high concentrations of organic matter and nitrogen in the soil.

\section{REFERENCES}

Barbanti, L. 1985. Some problems and new prospects on Physical Limnology. Limnology: a review. Mem. Istit. ital. Idrobiol., 43: 1-32.

Blais, J.M. \& J. Kalff. 1995. The influence of lake morphometry on sediment focusing. Limnol. Oceanogr., 40: 582-588.

Castro, M.C., M. Rivera, M. Crespo, J.M. Martín-García \& F. Guerrero. 2003. Morphological and sedimentological characterization of Honda temporary lake (southern Spain). Limnetica, 22(3-4): 147-154.

Carpenter, S.R. 1983. Lake geometry: Implications for production and sediment accretion rates. J. Theor. Biol., 105: 273-286.

Castellanos, J.Z., J.X. Uvalle-Bueno \& A. Aguilar-Santelises. 2000. Handbook for the Interpretation of Soil and Water Analysis. $2^{\text {nd }}$ ed. Colección Instituto de Capacitación para la Productividad Agrícola (INCAPA). San Miguel de Allende, Guanajuato, México: 226 pp.

Duarte, C.M. \& J. Kalff. 1988. Influence of lake morphometry on the response of submerged macrophytes to sediment fertilization. Can. J. Fish. Aquat. Sci., 45: 216-221.

Eloranta, P. 1986. Phytoplankton structure in different lake types in central Finland. Holarct. Ecol., 9: 214-224.

Farnham, I.M., J.S. Klaus, K.S. Ashok \& K.H. Johannesson. 2000. Deciphering groundwater flow systems in Oasis Valley, Nevada, using trace element chemistry, multivariate statistics, and geographical information system. Math. Geol., 32(8):943-968.

Guiral, J. \& E. Pérez. 1980. Based on a work plan and a study for projects on protection of humid areas. Bol. Estac. Centr. Ecol., 9: 19-26.

Güler, C., G.D. Thyne, J.E. Mccray \& K.A. Turner. 2002. Evaluation of graphical and multivariate statistical methods for classification of water chemistry data. Hydrogeol. J., 10: 455-474.

Håkanson, L. 1981. A manual of lake morphometry. Berlin: Springer-Verlag. Berlin, Heidelberg, New York: 78 pp.

Håkanson, L., A. Parparov \& K.D. Hambright. 2000. Modeling the impact of water level fluctuations on water quality (suspended particulate matter) in Lake Kinneret, Israel. Ecol. Model., 128: 101-125.

Kalff, J. 2002. Limnology. Inland water ecosystems. PrenticeHall, Inc New Jersey: 592 pp.

Lindström, M., L. Håkanson, O. Abrahamsson \& H. Johansson. 1999. An empirical model for prediction of lake water suspended particulate matter. Ecol. Model., 121: 185-198.

Naselli-Flores, L. 2003. Man-made lakes in Mediterranean semi-arid climate: the strange case of Dr Deep Lake and Mr Shallow Lake. Hydrobiologia, 506-509: 13-21.

Neumann, E. 1932. Grundzüge der regionalen Limnologie. Die Binnengewässer, 11(9): 176 pp.

Neumann, J. 1959. Maximum depth and average depth of lakes. J. Fish. Res. Board Can., 16: 923-927.

Ortega, F. \& F. Guerrero. 2003. Vegetación de las lagunas y humedales del Alto Guadalquivir. El complejo lagunar de Alcaudete-Valenzuela. In: Pérez Jiménez, J.Ma (ed.), In Memoriam al profesor Dr. Isidoro Ruiz Martínez. Universidad de Jaén, Jaén, España: 101-106.

Pick, F.F.A. \& C.W. Lean. 1987. The role of macronutrients (C, N, P) in controlling cyanobacterial dominance in temperate lakes. N. Z. J. Mar. Freshwat. Res., 21(3): 425434.

Pinel-Alloul, B., G. Méthot, G. Verrault \& Y. Vigneault. 1990. Phytoplankton in Quebec lakes: variation with lake morphometry, and with natural and anthropogenic acidification. Can. J. Fish. Aquat. Sci., 47: 1047-1057.

Ponce-Palafox, J.T. \& J.L. Arredondo-Figueroa. 1986. Aporte al conocimiento Limnológico de un embalse temporal tropical, por medio de la aplicación de modelos multivariados. An. Inst. Cienc. Mar y Limnol. Univ. Nal. Autón. México, 13(2):47-66.

Ponce-Palafox, J.T. \& J.L. Arredondo-Figueroa. 1998. An analysis of factors governing metabolism of temporary tropical freshwater pond ecosystems. Verh. Internat. Verein. Limnol., 26: 1571-1574.

Robertson, D.M. \& R.A. Ragotzkie. 1990. Thermal structure of a multibasin lake: influence of morphometry, interbasin exchange and groundwater. Can. J. Fish. Aquat. Sci., 47: 1206-1212.

Sakamoto, M. 1966. Primary production by phytoplankton community in some Japanese lakes and its dependence on lake depth. Arch. Hydrobiol., 62: 1-28.

Schindler, D.W. 1971. A hypothesis to explain differences and similarities among lakes in the Experimental Lakes Area, northwestern Ontario. J. Fish. Res. Board Can., 28: 295-301.

Smith, V.H. 1982. The nitrogen and phosphorus dependence of algal biomass in lakes: an empirical and theoretical analysis. Limnol. Oceanogr., 27: 1101-1112.

Soil Survey Staff. 1999. Soil Taxonomy: a basic system of soil classification for making and interpreting soil surveys. ( $2^{\text {nd }}$ ed.), USDA-NRCS Soil Conservation Service, Agricultural Handbook, 436. U.S. Government Printing Office, Washington, DC: $869 \mathrm{pp}$.

Sterner, R.W. 1990. Lake morphometry and light in surface layer. Can. J. Fish. Aquat. Sci., 47: 687-692.

Thienemann, A. 1925. Die Binnengewässer Mitteleuropas. Die Binnengewässer, 1: 1-255.

U.S. Department of Agriculture. 1972. Soil survey laboratory methods and procedures for collecting soil samples. Soil survey Investigation Report N. 1. Soil Conservation Service. Washington, DC. (US): 63 pp.

Wolt, J.D. 1994. Soil Solution Chemistry: application to environmental science and agriculture. John Wiley \& Sons, New York: 345 pp. 